\title{
Islet cell transplantation for the treatment of type I diabetes: recent advances and future challenges
}

This article was published in the following Dove Press journal:

Metabolic Syndrome and Obesity:Targets and Therapy

23 June 2014

Number of times this article has been viewed

\section{Anthony Bruni \\ Boris Gala-Lopez \\ Andrew R Pepper \\ Nasser S Abualhassan \\ AM James Shapiro}

Clinical Islet Transplant Program and Department of Surgery, University of Alberta, Edmonton, $\mathrm{AB}$, Canada

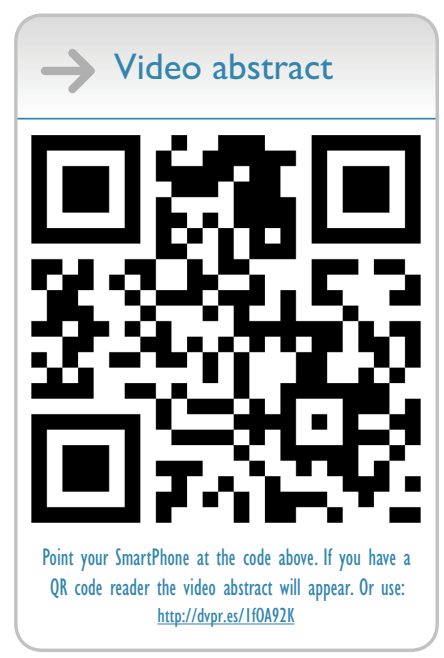

Correspondence: AM James Shapiro

Clinical Islet Transplant Program,

University of Alberta,

2000 College Plaza, 82 I5 I I th St,

Edmonton, AB T6G 2C8, Canada

Tel +l 7804077330

Fax +I 7804078259

Email amjs@islet.ca

\begin{abstract}
Islet transplantation is a well-established therapeutic treatment for a subset of patients with complicated type I diabetes mellitus. Prior to the Edmonton Protocol, only 9\% of the 267 islet transplant recipients since 1999 were insulin independent for $>1$ year. In 2000, the Edmonton group reported the achievement of insulin independence in seven consecutive patients, which in a collaborative team effort propagated expansion of clinical islet transplantation centers worldwide in an effort to ameliorate the consequences of this disease. To date, clinical islet transplantation has established improved success with insulin independence rates up to 5 years post-transplant with minimal complications. In spite of marked clinical success, donor availability and selection, engraftment, and side effects of immunosuppression remain as existing obstacles to be addressed to further improve this therapy. Clinical trials to improve engraftment, the availability of insulin-producing cell sources, as well as alternative transplant sites are currently under investigation to expand treatment. With ongoing experimental and clinical studies, islet transplantation continues to be an exciting and attractive therapy to treat type I diabetes mellitus with the prospect of shifting from a treatment for some to a cure for all.
\end{abstract}

Keywords: islet transplantation, type I diabetes mellitus, Edmonton Protocol, engraftment, immunosuppression

\section{Introduction}

Type 1 diabetes mellitus (T1DM) is a chronic, progressive autoimmune disorder characterized by destruction of insulin-producing $\beta$-cells within the pancreatic islets of Langerhans. Diabetes is a major source of morbidity and mortality due to progressive chronic micro- and macrovascular complications. The discovery of insulin by Banting et al has allowed diabetes to become a chronically manageable condition. ${ }^{1,2}$ Today intensive blood glucose monitoring and frequent daily administration of exogenous insulin delays progression of microvascular diseases, including retinopathy and neuropathy, but does not entirely prevent these complications. ${ }^{3}$ Concerted efforts to ameliorate the symptoms and complications of diabetes have spanned beyond administration of exogenous insulin to restoration of $\beta$-cell mass through islet transplantation.

The pioneering experiments by Lacy and Kostianovsky provided the fundamental means to introduce islet transplantation as an effective therapy to correct hyperglycemia through the ability to isolate a sufficient number of metabolically active and intact islets from rodent pancreata. ${ }^{4}$ While several authors reported correction of hyperglycemia in diabetic mice using varied islet doses and success via the intraperitoneal route, Reckard et al in 1973 were the first to effectively cure diabetes in a chemically induced model. ${ }^{5}$ Yet despite these successes, the same principles of isolation and purification could not 
be applied to larger animals or humans whose glands are more dense and fibrous. ${ }^{6}$

Refinements in the methods of islet isolation and purification for islet transplantation continued for decades with improved success in isolating significant quantities of highly pure islet preparations. The intraductal injection of collagenase proved an effective method for successful islet isolation from large animals and humans ${ }^{6,7}$ and modifications to this procedure progressed. However, the development of the Ricordi ${ }^{\circledR}$ Chamber (BioRep, Miami, FL, USA) in 1988 introduced a semi-automated process that was instrumental in consistently isolating and purifying large islet quantities. ${ }^{6,8}$ This method of islet isolation, in conjunction with improvements in islet purification and transplantation techniques, was paramount in the translation of islet transplantation from an experimental concept to an efficient clinical treatment modality for a selected group of patients suffering from T1DM. ${ }^{6}$

With a rising prevalence of T1DM and a limited supply of donor pancreata from scarce organ donors, ongoing efforts are being made to improve islet isolation practices and prevent islet loss, especially in the immediate post-transplant period through a series of strategies. ${ }^{9}$ Herein, we outline the current status of clinical islet transplantation, the obstacles associated with this practice, and strategies used to improve islet transplantation outcomes. Lastly, we introduce the prospect of modulating the immune system in an attempt to abolish the onset of T1DM to circumvent the necessity of therapeutic strategies like exogenous insulin administration or islet transplantation altogether.

\section{The evolution of clinical islet transplantation}

Outcomes in clinical islet transplantation have progressed significantly since its inception, in part due to improved islet manufacturing processes, coupled with more effective induction and maintenance immunosuppression to protect against both auto- and alloreactivity. ${ }^{10}$ Islet-alone transplantation has recently become an accepted practice to stabilize frequent hypoglycemia or severe glycemic lability in highly selected subjects with poor glycemic control. ${ }^{11}$ While Shcarp et al's work established the liver as an ideal site for islet transplantation, ${ }^{12}$ further work by Najarian et al in 1977 reported the first successful clinical islet transplant paired with the administration of azathioprine and corticosteroids. ${ }^{13}$ In spite of these advancements, $9 \%$ of the 267 islet transplant recipients since 1999 were insulin independent for $>1$ year. ${ }^{14}$ It was not until 2000 that the Edmonton Protocol reported insulin independence in seven consecutive T1D patients over a median follow-up of 11.9 months with sustained C-peptide. ${ }^{10}$ Of particular importance, patients had received at least two different islet transplants and a mean islet mass of 13,000 islet equivalents $/ \mathrm{kg}$, as well as a steroid-free immunosuppressive regimen with anti-interleukin-2 receptor antagonist antibody therapy, daclizumab. These results were pivotal in driving forward both interest and activity in clinical islet transplantation over the subsequent decade and resulted in the expansion of islet transplantation programs in North America and abroad through remarkable intercenter collaboration (Figure 1). ${ }^{15}$

\section{Current status of clinical islet transplantation}

Over the last decade, over 750 islet transplants have been performed in over 30 international transplant centers. Without doubt, islet transplantation has evolved from an experimental strategy to ameliorate the consequences of T1DM to a recognized standard clinical therapy. The therapy is only suitable in its current form for patients with unstable glycemic control that cannot be corrected by standard conventional and intensive insulin therapies. ${ }^{10}$ Patients with good glycemic control and children are not currently considered for islet transplantation on account of the need for lifelong chronic immunosuppression. A recent trial by Ly et al reported that sensor augmented pump therapy with automated insulin suspension reduced the rate of moderate and severe hypoglycemia, as well as impaired hypoglycemia awareness over a 6-month period in trial participants. However, when compared to the standard insulin pump control group, no change in glycosylated hemoglobin $\left(\mathrm{HbA}_{1 \mathrm{c}}\right)$ was observed. ${ }^{16}$ On the contrary, islet transplantation has the ability to correct $\mathrm{HbA}_{1 \mathrm{c}}$ to levels that can predictably reverse the secondary consequences of diabetes. ${ }^{17}$ In a one-way crossover study conducted by Thompson et al, it was demonstrated that clinical islet transplantation was more effective in reducing progression of diabetic retinopathy and nephropathy than intensive medical therapy. ${ }^{18}$ To this extent, the lifelong need for immunosuppressive therapy may be readily justified in this therapeutic setting.

In the most recent report released from the Collaborative Islet Transplant Registry (CITR), 677 allogeneic islet transplants have been reported. Results from the CITR indicate that $44 \%$ of recipients were insulin independent at 3 years post-transplant in "new era" of islet transplantation, from 2007-2010, as compared to $27 \%$ of clinical islet transplant recipients in 1999-2002..$^{15,19}$ Moreover, marked improvements in clinical islet transplantation have been observed 


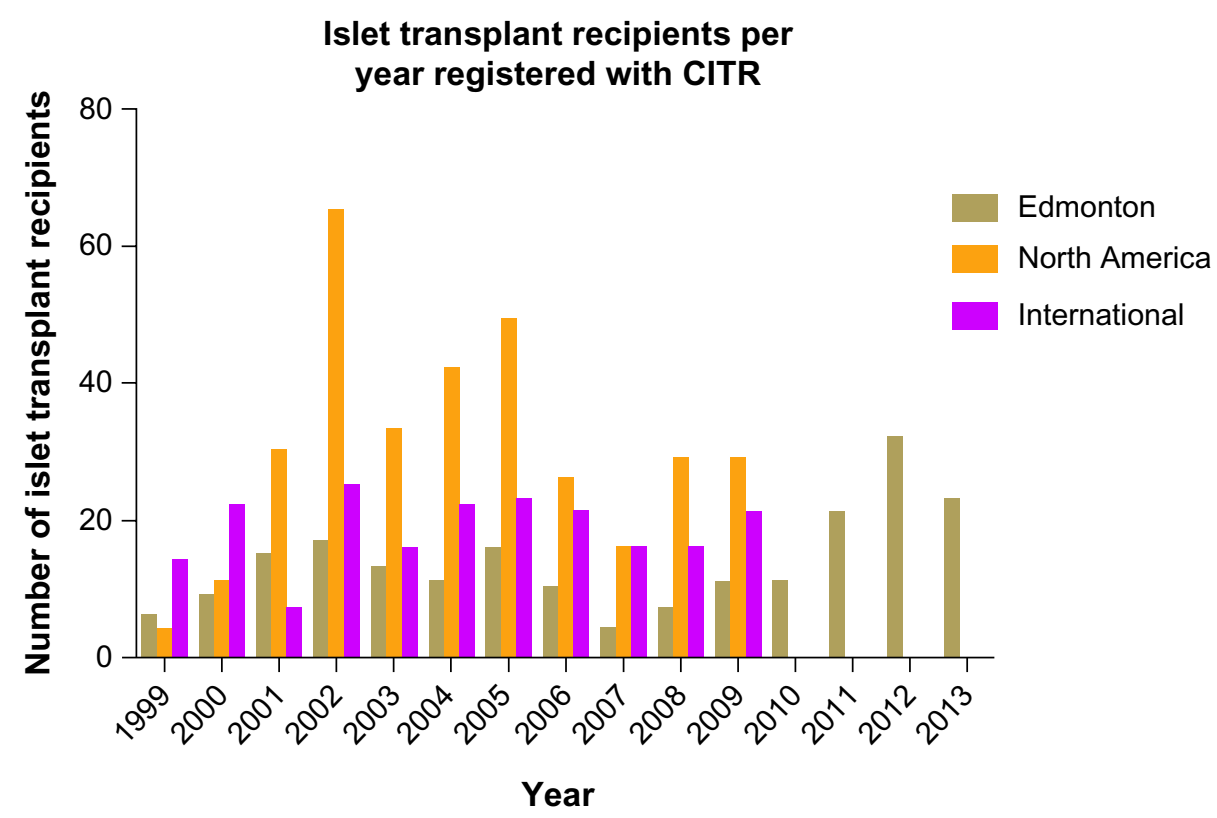

Figure I Number of islet transplant recipients from 1999-2013 in Edmonton, North America and International Islet Transplant Centers.

Notes: This data is kindly reproduced with express permission from the CITR Coordinating Center and Investigators. The Collaborative Islet Transplant Registry 201 I Seventh Annual Report. Reported data is unavailable from 2010-2013 for North America and International Islet Transplant Centers. ${ }^{15}$

Abbreviation: CITR, Collaborative Islet Transplant Registry.

from 2007-2010 as evidenced by retained C-peptide levels, reduction of $\mathrm{HbA}_{1 \mathrm{c}}$, and reduced islet reinfusion rates. ${ }^{19}$ This success, in part, can be attributed to shifts in immunosuppression strategies. However, improvements to islet engraftment and subsequent survival are critical in achievement of durable insulin-independence.

Within North America, few islet transplant centers are currently active despite the substantial transplant activity of international islet transplant centers. This is reflected in the classification of islet transplantation as an experimental therapy in the United States, resulting in a lack of available funds to conduct and support large scale clinical trials. Currently, two pivotal Phase III clinical trials are being conducted in specialized islet transplantation centers through the Clinical Islet Transplant (CIT) Consortium (CIT-06 and CIT-07, NCT00468117 and NCT00434811, respectively), in an effort to support the US Food and Drug Administration biological license application mandate. Successful licensure will inevitably recognize islet transplantation as a clinical therapy, expanding its therapeutic benefit for patients with T1DM in the United States.

The University of Alberta's Clinical Islet Transplant Program continues to be the most active center participating within the CITR. In 2013 alone, 66 islet transplants were conducted at the Edmonton site. The Edmonton group also reports that of over 200 patients transplanted with more than 400 intraportal islet preparations, $79 \%$ of recipients continue to show full or partial islet graft function. ${ }^{20}$ The median duration of insulin independence is 34.6 and 11 months for subjects with full or partial graft function, respectively, whereas the duration of C-peptide is 53.3 and 70.4 months, respectively, for those same patients. ${ }^{20-22}$

Prior to the Edmonton Protocol, insulin independence was an uncommon achievement. Though clinical success has improved markedly over the past 14 years, further obstacles must be overcome if islet transplantation is to be more broadly applied in the T1DM population. Such remaining challenges include expansion of the islet donor supply, improving islet isolation techniques, strategies to improve engraftment, mediating the anti-inflammatory response post-transplant, and improving recipient immunosuppression regimens. Several clinical trials are currently under active investigation to address these obstacles in an attempt to improve this important therapy (Table 1).

\section{Clinical islet transplantation: obstacles and refinements Donor selection and availability}

The number of pancreas donors required to treat one recipient limits the number of transplants that can occur. A component of islet transplantation that may improve clinical outcomes is donor selection. Retrospective studies at single centers have identified several donor-related variables that may contribute to islet isolation outcomes. These variables include donor 
Table I Summary of current clinical trials with refinements in islet transplantation

\begin{tabular}{|c|c|c|c|c|}
\hline Category & Trial ID & Description & Institution & $\begin{array}{l}\text { Estimated } \\
\text { completion date }\end{array}$ \\
\hline Islet alone & NCT004348II & $\begin{array}{l}\text { Islet transplantation in type I diabetes - } \\
\text { phase } 3 \text { (CIT-07) }\end{array}$ & $\begin{array}{l}\text { National Institute of Allergy } \\
\text { and Infectious Diseases }\end{array}$ & May 2014 \\
\hline \multirow[t]{5}{*}{ Islet - Kidney } & NCT0II23I87 & $\begin{array}{l}\text { Islet cell transplantation in patients with type I } \\
\text { diabetes with previous kidney transplantation }\end{array}$ & University Hospital, Lille & March 2015 \\
\hline & NCT0I24I864 & $\begin{array}{l}\text { Islet transplantation in type I diabetic } \\
\text { kidney allograft }\end{array}$ & University of Chicago & December 2016 \\
\hline & NCT0I705899 & $\begin{array}{l}\text { Islet allotransplantation in type I diabetes: } \\
\text { phase I trial comparing islet alone vs islet } \\
\text { after kidney transplantation }\end{array}$ & Ohio State University & May 2017 \\
\hline & NCT00784966 & Islet after kidney transplant for type I diabetes & $\begin{array}{l}\text { Virginia Commonwealth } \\
\text { University }\end{array}$ & September 2017 \\
\hline & NCT00468II7 & $\begin{array}{l}\text { Efficacy of islet after kidney transplantation - } \\
\text { phase } 3 \text { (CIT-06) }\end{array}$ & $\begin{array}{l}\text { National Institute of Allergy } \\
\text { and Infectious Diseases }\end{array}$ & December 2018 \\
\hline \multirow[t]{4}{*}{$\begin{array}{l}\text { Alternative } \\
\text { transplant sites }\end{array}$} & NCT00790257 & $\begin{array}{l}\text { Safety and efficacy study of encapsulated human } \\
\text { islets allotransplantation to treat type I } \\
\text { diabetes (subcutaneous space) }\end{array}$ & $\begin{array}{l}\text { Cliniques universitaires } \\
\text { Saint Luc Université } \\
\text { Catholique de Louvain }\end{array}$ & December 2013 \\
\hline & NCT0I722682 & $\begin{array}{l}\text { Bone marrow versus liver as site for islet } \\
\text { transplantation }\end{array}$ & Ospedale San Raffaele & November 2014 \\
\hline & NCT0I6529II & $\begin{array}{l}\text { A phase I/II study of the safety and efficacy } \\
\text { of sernova's Cell Pouch }{ }^{\mathrm{TM}} \text { for therapeutic } \\
\text { islet transplantation (subcutaneous space) }\end{array}$ & University of Alberta & December 2014 \\
\hline & NCT0I 379729 & $\begin{array}{l}\text { Functional survival of beta cell allografts } \\
\text { after transplantation in the peritoneal cavity } \\
\text { of non-uremic type I diabetic patients }\end{array}$ & $\begin{array}{l}\text { Ziekenhuis Brussel/ } \\
\text { Ziekenhuizen Leuven } \\
\text { Belgium }\end{array}$ & May 2018 \\
\hline \multirow[t]{2}{*}{ Complications } & NCTOII 48680 & $\begin{array}{l}\text { Trial comparing metabolic efficiency of islet } \\
\text { graft to intensive insulin therapy for type I } \\
\text { diabetes treatment }\end{array}$ & $\begin{array}{l}\text { University Hospital, } \\
\text { Grenoble }\end{array}$ & December 2014 \\
\hline & NCT00853424 & $\begin{array}{l}\text { A comparison of islet cell transplantation } \\
\text { with medical therapy for the treatment } \\
\text { of diabetic eye disease }\end{array}$ & $\begin{array}{l}\text { University of British } \\
\text { Columbia }\end{array}$ & June 2015 \\
\hline \multirow[t]{10}{*}{$\begin{array}{l}\text { Refined portal } \\
\text { vein protocols }\end{array}$} & NCT00679042 & $\begin{array}{l}\text { Islet transplantation in type I diabetic patients } \\
\text { using the University of Illinois at Chicago } \\
\text { protocol }\end{array}$ & University of Illinois & December 2013 \\
\hline & NCT00789308 & $\begin{array}{l}\text { Safety and effectiveness of low molecular } \\
\text { weight sulfated dextran in islet transplantation }\end{array}$ & $\begin{array}{l}\text { National Institute of Allergy } \\
\text { and Infectious Diseases }\end{array}$ & August 2014 \\
\hline & NCT0I8I7959 & $\begin{array}{l}\text { Study to assess efficacy and safety of reparixin } \\
\text { in pancreatic islet transplantation }\end{array}$ & Multi-Centers International & November 2014 \\
\hline & NCT00530686 & $\begin{array}{l}\text { Pancreatic islet cell transplantation - a } \\
\text { novel approach to improve islet quality } \\
\text { and engraftment }\end{array}$ & Baylor Research Institute & December 2014 \\
\hline & NCT0I653899 & Caspase inhibition in islet transplantation & University of Alberta & June 2015 \\
\hline & NCT0I897688 & $\begin{array}{l}\text { A phase } 2 \text { single center study of islet } \\
\text { transplantation in non-uremic diabetic patients }\end{array}$ & Northwestern University & June 2015 \\
\hline & NCT0II 86562 & $\begin{array}{l}\text { Sitagliptin therapy to improve outcomes } \\
\text { after islet autotransplant }\end{array}$ & University of Minnesota & September 2015 \\
\hline & NCT0I 630850 & $\begin{array}{l}\text { Islet transplantation in patients with (brittle) } \\
\text { type I diabetes }\end{array}$ & University of Chicago & June 2019 \\
\hline & NCTOI 974674 & $\begin{array}{l}\text { Allogeneic islet transplantation for the } \\
\text { treatment of type I diabetes (GRIIF) }\end{array}$ & $\begin{array}{l}\text { Assistance Publique - } \\
\text { Hôpitaux de Paris }\end{array}$ & January 2021 \\
\hline & NCT0I909245 & Islet cell transplant for type I diabetes (TCD) & City of Hope Medical Center & July 2021 \\
\hline \multirow[t]{3}{*}{$\begin{array}{l}\text { Alternative } \\
\text { cellular therapies }\end{array}$} & NCT00646724 & $\begin{array}{l}\text { Co-transplantation of islet and mesenchymal } \\
\text { stem cell in type I diabetic patients }\end{array}$ & Fuzhou General Hospital & January 2014 \\
\hline & NCT0I350219 & Stem cell educator therapy in type I diabetes & $\begin{array}{l}\text { Tianhe Stem Cell } \\
\text { Biotechnologies Inc. }\end{array}$ & September 2014 \\
\hline & NCT0I736228 & $\begin{array}{l}\text { Open-label investigation of the safety and } \\
\text { efficacy of DIABECELL in patients with TIDM: } \\
\text { xenotransplantation of encapsulated porcine } \\
\text { islets into the peritoneal cavity }\end{array}$ & Living Cell Technologies & December 2014 \\
\hline
\end{tabular}


Table I (Continued)

\begin{tabular}{lllll}
\hline Category & Trial ID & Description & Institution & $\begin{array}{l}\text { Estimated } \\
\text { completion date }\end{array}$ \\
\hline NCTOI34I899 & $\begin{array}{l}\text { Efficacy and safety study of autologous } \\
\text { hematopoietic stem cell transplantation } \\
\text { to treat new onset type I diabetes }\end{array}$ & Nanjing University & Medical School & December 20I5 \\
& A trial of high dose immunosuppression and & University of Sao Paulo & December 20I6 \\
& autologous hematopoietic stem cell support & General Hospital & \\
& versus intensive insulin therapy in adults & & \\
& with early onset TIDM & & \\
\hline
\end{tabular}

Abbreviations: CIT, Clinical Islet Transplant; GRIIF, allogeneic islet transplantation for the treatment of type I diabetes; TIDM, type I diabetes mellitus; TCD, T-cell depletion.

age, cause of death, body mass index (BMI), cold ischemia time, length of hospitalization, use of vasopressors, and blood glucose levels. ${ }^{23-30}$ In most cases, a larger pancreas contains a larger $\beta$-cell mass, however, pancreas weight is not a donor selection criterion since a value cannot be obtained prior to procurement. ${ }^{29,31}$ In a study analyzing data from 345 deceased donors, it was determined that BMI correlates with pancreas weight but body surface area is a better predictor of pancreas weight than BMI. ${ }^{31}$ Several groups have indicated that BMI positively affects islet yield, ${ }^{32}$ which leads many to consider BMI as an important donor factor influencing islet isolation outcome. ${ }^{27-29}$ However, this view has led to the misconception that an obese donor is a good candidate for successful islet isolation and transplantation. To date, "optimal" pancreata are allocated for whole organ transplantation in most centers, as this procedure has historically established success in single-donor transplant scenarios. This procedure is not without inherent perioperative risks. Supporting this notion is a recent report by Berney and Johnson who conclude that the islet mass transplanted does not unequivocally correlate with islet graft function. Further arguing that based on these premises donor selection criteria for islet transplantation and hence allocation rules (pancreas for whole organ or islet transplant) may need to be redefined..$^{33}$

A scoring system based on donor characteristics that can predict islet isolation outcomes was previously developed by O'Gorman et al and has been an instrumental tool in assessing whether a pancreas should be processed for islet isolation. ${ }^{34,35}$ Though this tool has been sufficient in determining organs for islet isolation, it does not predict islet transplant outcome. Similarly, other published studies dealing with donor factors do not take transplant outcome into consideration. ${ }^{23,24,26-30}$ A prospective scoring system that takes both islet isolation and transplantation outcomes into consideration would be more advantageous.

Expansion of organs available for islet transplantation may be made possible through the use of donation after cardiac death (DCD) donors. The use of DCD donors compared to their brain dead counterparts has varied results and may not be entirely promising. Japan has extensive experiences with DCD donors for organ transplantation and has optimized retrieval practices in these donors, as well as the Kyoto preservation solution and the two-layer preservation method. ${ }^{36}$ In the most recent report for islet transplantation from DCD donors, overall graft survival was $76.5 \%, 47.1 \%$, and $33.6 \%$ at 1,2 , and 3 years, respectively. ${ }^{37}$ Moreover, corresponding graft survival after multiple transplantations was $100 \%$, $80.0 \%$, and $57.1 \%$, respectively. Islet transplant recipients remained free from severe hypoglycemic episodes, while three achieved insulin independence for 14, 79, and 215 days. ${ }^{37}$ These encouraging results suggest the benefit of DCD as an expanded organ source for islet transplantation, particularly in countries where heart beating donors may not be readily available, though strict release criteria may be imperative to achieve desirable and consistent transplant outcomes.

\section{Pancreas digestion and islet isolation}

Due to the multifaceted composition of the pancreas, islet isolation from the pancreas involves dissociation of islets from the exocrine pancreas by enzymatic digestion combined with mechanical agitation. Successful islet transplantation is initially contingent on the isolation of high islet yields, ensuring that this process inflicts significantly minimal damage. Subsequent to isolation, islets are then purified by density gradient centrifugation. To ensure optimal isolation will provide a sufficient islet yield without compromising high purity, integrity, and viability, a critical balance of composition, process, and duration of collagenase digestion is required. ${ }^{38}$ The enzymatic digestion process disrupts isletto-exocrine tissue adhesive contact. Suboptimal collagenase composition leads to incomplete digestion of islets from exocrine tissue along with reduced yield, decreased purity, increased duration of collagenase exposure adversely affects 
within-islet cell-to-cell adhesion, leading to loss of islet integrity and viability. Thus, the use of highly pure and intact collagenase preparations is desirable to isolate pure islets with the least possible damage to the islets themselves. ${ }^{39}$ The culturing of islets postisolation is critical for their recovery from isolation-induced damage, however this may be at the cost of impaired revascularization subsequent to transplant, due to the loss of intraislet endothelial cells during this culture period. Sufficient oxygen and nutrient supply is a primary aim of culture conditions for human islet preparations. Moreover, the maintenance of the tridimensional islet cluster, as well as preventing islet mass loss should also be accomplished during the culturing phase. Though sufficient investigation of optimal culture conditions has occurred to date, protocols have yet to be standardized, and culture conditions may vary between islet isolation centers. ${ }^{40}$ Other considerations like media composition, seeding density, and incubation temperature play a significant role in maintaining viability and recovery. ${ }^{40}$

Further to extracellular culture requirements, the use of slightly impure islet preparations and coculture with extracellular matrix components like collagen were shown to enhance the viability and function of isolated islets. ${ }^{41}$ In addition, islet coculture with pancreatic ductal epithelial cells were also shown to maintain islet viability and function postisolation. ${ }^{42}$ One essential component of the extracellular matrix, pancreatic ductal epithelial cells have been considered as putative stem cells for islets. The cells have been shown to play a critical role in secreting appropriate growth factors that support islet viability. In a pivotal study by Gatto et al, culturing techniques, like long-term culture and cryopreservation, had a negative impact on the viability of human islet preparations. These events were shown to be ameliorated when cocultured with ductal epithelial cells at $33^{\circ} \mathrm{C} .^{43}$ It has also been established that coculture of islets with ductal epithelial cells assisted with the maintenance of structural integrity and prolonged viability. ${ }^{39}$ Due to the conditions of the islet isolation procedure, islets become disconnected from their blood supply. As a result, hypoxic events during culture impact islet viability. ${ }^{44,45}$ Although it may be difficult to prevent a hypoxic condition of the inner islet cell mass during in vitro culture, genetic modulation of islets to express genes that promote rapid revascularization upon transplantation and reduced culture time could play an important role in preventing hypoxic damage to the islets. ${ }^{46}$ Furthermore, the use of chemical agents that attenuate the downstream effects of hypoxia during culture may also be a feasible strategy to improve islet viability postisolation and prior to transplantation.

\section{Islet engraftment}

After transplantation, to adequately survive and function, islets depend heavily on the diffusion of oxygen and nutrients from the surrounding microenvironment. To regain proper islet function, new capillaries and blood vessels form to rebuild their old capillary network. The new network is derived from both the recipient blood vessels and from the remnant donor islet endothelium. This revascularization process may initiate as soon as 1-3 days post-transplant and may conclude around day $14 .{ }^{47}$ Multiple studies report the enormous stress to which the islets are exposed during the first days after transplant. ${ }^{39,47,48}$ Multiple factors combine and contribute to apoptosis and cell death, resulting in islet tissue loss of around $60 \%{ }^{47}$

Research efforts to improve intrahepatic islet delivery have identified multiple mechanisms that limit islet engraftment and long-term function. Intrahepatic transplantation is a minimally invasive portal infusion that results in islet entrapment within hepatic sinusoids. This vascular space provides nutritional and physical support for islets, which is an essential role given that the islet isolation process strips the islets of their dense vasculature and specialized extracellular matrix. ${ }^{49,50}$ However, the hepatic portal vasculature can also be considered as a hostile environment that limits islet engraftment and function. ${ }^{51}$ For example, although the liver offers an abundant vascular supply, parenchymal oxygen tension is well below that of the pancreas and is not conducive to islet survival. ${ }^{52,53}$ Since many more islets must be transplanted to reverse diabetes, a significant portion of the transplanted islets fails to engraft and become functional. It has been estimated that up to $70 \%$ of the transplanted $\beta$-cell mass may be destroyed in the early post-transplant period. ${ }^{68}$

A primary culprit of acute graft loss is the instant bloodmediated inflammatory reaction (IBMIR), which negatively influences islet engraftment through expression of tissue factor, resulting in platelet adherence, activation, clot formation, and lymphocyte recruitment. ${ }^{9,54}$ The direct impact of IBMIR on early loss of islet function and mass has yet to be fully characterized. However, given that platelet activation is one of the primary contributing factors in the generation of an inflammatory response, IBMIR is most likely one of the key processes that elicits an early immune response. ${ }^{55-59}$ In a study conducted by the Uppsala Group, it was demonstrated that IBMIR is initiated upon intraportal infusion. ${ }^{60}$ Further to IBMIR, inflammatory events, like the activation of natural killer T-cells have also been linked to early islet loss associated with intraportal infusion. ${ }^{61}$

During engraftment, transplanted islets are continuously exposed to immunosuppressive drugs, including tacrolimus and sirolimus, which are known to adversely impact $\beta$-cell 
survival and function. ${ }^{62}$ Taken together, these negative effects are likely compounded by the proximity of the transplanted islets to high concentrations of these drugs in the hepatoportal circulation, further contributing to loss in $\beta$-cell mass over time. ${ }^{63}$

Strategies to monitor islets postintraportal infusion have provided valuable insights to acute islet engraftment but have been limited in their implementation long-term. To be clinically relevant, the ideal imaging modality should be noninvasive, nontoxic to islets, and allow for serial imaging over time in the same patient. ${ }^{64}$ To date, magnetic resonance imaging (MRI) and positron emission tomography (PET) are at the forefront of intraportal islet imaging. Though MRI has the ability to provide high spatial resolution, it lacks longterm application, as iron overload has been a primary technical obstacle. ${ }^{65,66} \mathrm{~A}$ recent preclinical study using cationic nanoparticle-labeled mouse islets showed superior uptake efficiency while yielding in vivo function as evidenced by restoration of normoglycemia in kidney capsule recipients. ${ }^{67}$ Ultimately, translation of this promising method to the clinical setting will require successful uptake in human islet preparations, illustrate in vivo function when transplanted intraportally, and have the ability to be imaged long-term.

While the spatial resolution of PET is low compared to MRI, it offers superior sensitivity and specificity when using $\left[{ }^{18} \mathrm{~F}\right]$ fluoro deoxy-glucose-labeled islets. This modality was essential in elucidating islet loss in the acute transplant phase. ${ }^{68,69}$ In spite of the advantages associated with PET, long-term utility of this imaging modality is primarily limited to washout of radioactive tracers once islets have made contact with blood in the portal vein. ${ }^{69}$ Without question, the ability to overcome the obstacles associated with these imaging modalities will be paramount in improving engraftment outcomes.

\section{Alternative islet transplantation sites}

Today, intrahepatic islet infusion via the portal vein accounts for virtually all clinical islet transplants conducted worldwide. While percutaneous portal vein infusion offers a minimally invasive procedure with the ability to regulate glycemic levels through portal insulin delivery, ${ }^{70}$ it is not without potential procedural risks such as portal thrombosis and bleeding. ${ }^{71}$ A significant amount of intraportal islet mass is lost immediately post-transplant due to innate immune pathways involving platelet and complement activation described in the "Islet engraftment section". As such, extrahepatic islet transplantation has drawn focused attention recently to identify an optimal site to achieve sustained post-transplant insulin independence.
An ideal engraftment site should provide an adequate space to accommodate a large volume of transplanted islets, within close proximity to vascular networks supplying sufficient oxygen and nutrients during the revascularization period. Moreover, the site should prevent early islet loss due to host inflammatory reactions, while also providing accessibility for transplantation procedures and retrievability, if necessary. ${ }^{72}$ Retrievability is paramount should insulin-producing stem cells therapies be translated into clinical practice.

Numerous sites have been proposed and tested, both experimentally and in some cases clinically, including the liver, kidney subcapsule, spleen, pancreas, omentum, gastrointestinal wall, immune privileged sites, and subcutaneous spaces. While some alternative sites may be advantageous in experimental models, their feasibility and translation into clinical settings is limited to date. For example, when compared to intraportal infusion in mice, a smaller islet mass is required to reverse hyperglycemia in the renal subcapsular space. ${ }^{73,74}$ Clinically, however, the renal subcapsular site is less favorable, as a greater islet mass is required than intraportal infusion and is much more invasive surgically. ${ }^{75}$ Pepper et al and Vériter et al have summarized the utility of alternative transplant sites in experimental models and their prospective applicability to the clinical setting. ${ }^{72,76}$

Of the alternative transplant sites studied to date, the subcutaneous space may be considered attractive for multiple reasons. The subcutaneous site offers accessibility, and potential for biopsy access. ${ }^{70}$ Subcutaneous transplantation of islets has been developed using alternative approaches including preimplantation and vascularization of subcutaneous devices, encapsulation of islets, or a combination of both approaches. ${ }^{72}$ Subcutaneous devices can be easily implanted, accessed for subsequent transplantation, as well as retrieved. ${ }^{72,77}$ The subcutaneous space is limited however by its poor blood supply, which may considerably compromise islet function and engraftment. Experimental studies support this notion, as prevascularized devices prior to transplantation increased islet survival, as evidenced by improvements in hyperglycemia. ${ }^{78,79}$ When immuneisolating devices are placed under the skin, they may require an enhanced oxygen supply from an external source, as they are impermeable to vascular ingrowth. Currently, this technology is being tested in preclinical and clinical studies through the use of an implantable bioartificial pancreas. ${ }^{80,81}$ Barkai et al have reported that an enhanced subcutaneous bioartificial pancreas containing a refillable oxygen reservoir was capable of maintaining islet function, 
as well as demonstrating immunoprotective characteristics in allogeneic and xenogeneic models. ${ }^{80}$ Moreover, in an allogeneic human islet transplant setting using the same subcutaneous device, prolonged graft function and regulated insulin secretion without the need for immunosuppressive therapy was demonstrated. ${ }^{81}$ The prospect of such a device is an attractive option in that it can be easily retrieved, reduces need for chronic immune suppression and may expand the utility of insulin-producing cells from an alternative supply, including stem cells and xenogeneic sources.

While intraportal islet infusion has clinically demonstrated the ability to abrogate T1DM, there continues to be an ongoing need to identify an alternative transplant site to optimize long-term clinical outcomes. Experimental investigation has provided potential alternatives to restore normoglycemia, although some approaches have suggested technical and/or physiological limitations. Conversely, other extrahepatic sites may hold promise in promoting $\beta$-cell viability, restoration of indefinite normoglycemia, and the prospect of eliminating immunosuppression in the allograft recipient.

\section{Alternative sources of insulin-producing cells}

Improving the availability of insulin-producing cells can also be achieved through the generation of $\beta$-cells from human pluripotent stem cells. In a pivotal study by D'Amour et al, human pancreatic hormone-producing cells were developed in vitro from a human pluripotent stem cell source. Examination of the insulin-expressing cells in these cultures, however, revealed a polyhormonal and nonfunctional phenotype. ${ }^{82}$ Subsequent to these studies, Kroon et al developed pancreatic endoderm derived from human embryonic stem cells. Notably, functional endocrine cells were generated in vivo when pancreatic endoderm was engrafted in immune compromised mice. The insulin-expressing cells generated postengraftment exhibited properties of functional $\beta$-cells and were capable of restoring normoglycemia when transplanted in diabetic mice. ${ }^{83}$ These studies were fundamental in the establishment of a robust methodology for consistent, large scale production of this cellular source by Schulz et al ${ }^{84}$ which will undoubtedly serve as a platform to circumvent cadaveric donor shortages by providing a potentially unlimited supply of insulin-producing cells for clinical application.

\section{Improvements in immunosuppression}

The Edmonton Protocol established the immunosuppression scheme that utilized the combination of sirolimus, low dose tacrolimus, and daclizumab in an effort to prevent the deleterious effects of calcineurin inhibitors and steroids. ${ }^{85}$ However, insulin independence was not durable long-term, as most patients returned to modest amounts of insulin despite the elimination of recurrent hypoglycemia by 5 years post-transplant, clearly indicating room for improvement. ${ }^{86}$ Undoubtedly, a primary challenge to islet transplantation is the prevention of alloreactivity in addition to the recurrence of autoimmunity against insulin producing $\beta$-cells. ${ }^{86}$

It is unlikely that a monotherapy will optimize clinical islet transplantation outcomes and lead to single donor recipients, due to the multiple pathways known to contribute to $\beta$-cell attrition, as well as the alloresponse to foreign antigens. ${ }^{86}$ The implementation of highly potent and selective biological agents for the initiation and maintenance of immunosuppression has made significant progress in reducing the frequency of acute rejection, prolonging graft survival, and minimizing the complications of these therapeutic schemes. ${ }^{6,87}$ Improvements to single donor success rates were reported at the University of Minnesota through combining anti-inflammatory biologics to maintenance immunosuppression. ${ }^{88,89}$ In addition, peritransplant insulin and heparin administration greatly increased the success rate of single donor islet transplants from $10 \%$ to $40 \%{ }^{90}$ Furthermore, the blockade of tumor necrosis factor-alpha with etanercept has also enhanced single donor islet transplant outcomes. ${ }^{89-93}$

The clonal depletion of alloreactive T-cells appears to promote a hyporesponsive environment and peripheral mechanisms of anergy, thus driving the shift towards tolerance. $^{94,95}$ Substantial improvements in long-term insulin independence ( $>5$ years) have been made possible through induction agents such as alemtuzumab in conjunction with tacrolimus/mycophenolate mofetil that drive the process of T-cell depletion. ${ }^{17}$ Combined immunosuppressive strategies have shown significant therapeutic benefit as reported by Posselt et al. In the absence of calcineurin inhibitors, costimulation blockage using belatacept (inhibiting CD80-CD86 interactions) in conjunction with T-cell depletion induction led to insulin independence with islets from a single donor and prolonged allograft survival. ${ }^{96}$

The long-term success of islet transplantation, in part, is contingent on the successful establishment of an immunosuppressive regimen that promotes self-tolerance. A tolerizing regimen that utilizes biologics and techniques that selectively target donor reactive T-cells while expanding populations of regulatory T-cells, in an "islet friendly" manner will undoubtedly lead to the definitive cure of T1DM. 


\section{Immunomodulation: a method to prevent TIDM?}

While obstacles and risks associated with islet transplantation still exist, alternative strategies to eliminate the onset of T1DM through immunomodulation have been proposed in experimental and clinical settings. Investigation of such strategies has been implemented in an effort to prevent the progression of $\beta$-cell destruction and clinical disease onset without the need to transplant islets to restore euglycemia. To effectively establish such a feat would require identification of genetic, immunologic, and metabolic parameters linked to T1DM. ${ }^{97}$ Although extensive efforts have been made to identify such markers, success in these studies has been limited. ${ }^{98}$ This can be attributed to the multicomponent and heterogeneous immunologic response between patients that renders single component therapies useless in preventing disease onset. ${ }^{97}$ The aim of immunomodulation in T1DM, albeit through pharmacological or cellular replacement therapies, is to enhance regulatory immune cells to restore self-tolerance or eliminate pathogenic cells responsible for the destruction of pancreatic $\beta$-cells.

Pharmacological approaches of immune modulation to date include antigen-specific agents, as well as nonantigen specific agents. An example of antigen-specific immune therapies undergoing clinical investigation include glutamate decarboxylase (GAD)65, identified over 20 years ago as a $\beta$-cell specific autoantigen. ${ }^{99}$ Experimental and clinical studies exploiting GAD65 in T1DM onset have elicited conflicting results between animal and human trials. For example, the spontaneous onset of T1DM in nonobese diabetic mice was abrogated when treated with recombinant GAD65. ${ }^{100,101}$ Conversely, a recent trial has established that immunization with GAD65 was ineffective in ameliorating $\beta$-cell destruction in patients with recent onset diabetes. ${ }^{102} \mathrm{~A}$ critical component to these contradictory findings is the temporal relationship between therapeutic administration and disease onset. In NOD mice, treatment occurred prior to the onset of disease, while administration in humans occurred after the clinical manifestation of the disease. ${ }^{103}$ Taken together, these observations emphasize the importance of identifying markers for disease onset so that such therapies can be useful in rescuing from disease.

An example of nonantigen specific pharmacological agents used as a prospective immunomodulatory therapy is the use of teplizumab, an FcR nonbinding anti-CD3 monoclonal antibody. FcR nonbinding of anti-CD3 induces adaptive regulatory T-cells as evidenced from preclinical and clinical studies. ${ }^{104,105}$ Anti-CD3 is among the most extensively studied immunological approaches to abrogate T1DM. ${ }^{106}$ Compelling preclinical results using anti-CD3 in diabetic NOD mice elucidated prolonged remission of disease and achievement of immunologic tolerance. ${ }^{105,107} \mathrm{~A}$ recent trial further established a protective effect on $\beta$-cell function for 1 to 2 years as indicated by preserved $\mathrm{C}$-peptide levels though protective effects diminished and disease progression ensued in some recipients. ${ }^{108}$ Further clinical investigation into the approach to ameliorate disease onset using anti-CD3 is warranted based on preclinical and clinical outcomes observed to date.

The evaluation of pharmacological agents as an immune intervention to prevent residual $\beta$-cell loss and reestablish the autoimmune response has been evaluated in many clinical trials. ${ }^{109-112}$ Although these therapies showed an improvement in C-peptide levels when compared to placebo groups, these effects were not maintained when immunosuppressive therapies were discontinued. As a means to circumvent this event, a pivotal study by Voltarelli et al established a therapy of high dose cyclophosphamide administration followed by autologous nonmyeloablative hematopoietic stem cell transplantation in newly diagnosed T1DM patients. The compelling results of this clinical trial established self-tolerance, as evidenced by increased C-peptide levels and insulin independence in 93\% of the study participants. It should be noted, however, that the mechanism of tolerance in this instance is not fully understood and cannot be definitively attributed to either T-cell regulatory suppression or clonal deletion. ${ }^{113}$ While this study does show promise, the use of a potentially toxic immunosuppressive agent like cyclophosphamide may not warrant this as a prospective therapy to prevent T1DM due to long-term complications related to high dose cyclophosphamide. The goal to establish "immunological reset" to prevent $\beta$-cell destruction and the onset of T1DM is an attractive therapy that may be attainable with the use of more safe and effective immunosuppressive therapies and anti-inflammatory agents, paired with autologous stem cell transplantation.

\section{Conclusion}

Undoubtedly, islet isolation and transplantation, introduction of the Edmonton Protocol, and subsequent important developments internationally have played major roles in improving the results and activity of clinical islet transplantation. While islet transplantation cannot currently be defined as a cure for T1DM, the therapy can offer remarkable stability of glycemic control and correction of $\mathrm{HbA}_{1 \mathrm{c}}$, providing an increasing number of patients with sustained periods of complete independence from insulin. Prevention of life threatening hypoglycemia is a major advancement that can often not be 
sustained by optimized exogenous insulin therapy. In parallel to the strategies implemented to overcome limitations associated with islet transplantation, alternative methods to drive self-tolerance and prevent the onset of T1DM are also under investigation. Nevertheless, concerted efforts to improve the lives of those afflicted with T1DM rapidly drive the transition from experimental research to clinical care.

\section{Acknowledgments}

$\mathrm{AB}$ is supported though a scholarship from the Alberta Diabetes Institute/University of Alberta. ARP received a MITACS government of Canada-Industry-Academic partnership grant. BG-L is supported through the Izaak Walton Killam Scholarship, and also receives support through AIHS CRIO Team Award (grant \#201201154). NSA is supported by a scholarship from the Government of Saudi Arabia. AMJS is supported through a Canada Research Chair (CRC) in Transplantation Surgery and Regenerative Medicine, and through a Senior Clinical Scholarship from Alberta Innovates Healthcare Solutions (AIHS). The clinical islet transplant program is supported through Alberta Healthcare, and receives research support through the Collaborative Islet Transplant Consortium (CIT) funded through the National Institutes of Health (NIH), National Institute of Digestive Diseases and Kidney (NIDDK) and through the National Institute of Allergy and Infectious Diseases (NIAID). The islet program also receives funding through the Juvenile Diabetes Research Foundation (JDRF), and through the Diabetes Research Institute Foundation of Canada (DRIFCan). This work is part of the Canadian National Transplant Research Program (CNTRP) and was supported by the CIHR and partners (Grant Number TFU 127880).

The authors thank the Collaborative Islet Transplant Registry for granting access to their Seventh Annual Report.

\section{Disclosure}

The authors declare no conflict of interest in this work.

\section{References}

1. Polonsky KS. The past 200 years in diabetes. New Engl J Med. 2012;367(14):1332-1340.

2. Banting FG, Best CH, Collip JB, Campbell WR, Fletcher AA. Pancreatic extracts in the treatment of diabetes mellitus. Can Med Assoc J. 1922;12(3):141-146.

3. Agarwal A, Brayman KL. Update on islet cell transplantation for type 1 diabetes. Semin Intervent Radiol. 2012;29(2):90-98.

4. Lacy PE, Kostianovsky M. Method for the isolation of intact islets of Langerhans from the rat pancreas. Diabetes. 1967;16(1):35-39.

5. Reckard CR, Ziegler MM, Barker CF. Physiological and immunological consequences of transplanting isolated pancreatic islets. Surgery. 1973;74(1):91-99.
6. Shapiro AM. A historical perspective on experimental and clinical islet transplantation. In: Shapiro AMJ, Shaw JAM, editors. Islet Transplantation and Beta Cell Replacement Therapy. New York: Informa Health Care; 2007:1-18.

7. Lakey JR, Warnock GL, Shapiro AM, et al. Intraductal collagenase delivery into the human pancreas using syringe loading or controlled perfusion. Cell Transplant. 1999;8(3):285-292.

8. Ricordi C, Lacy PE, Scharp DW. Automated islet isolation from human pancreas. Diabetes. 1989;38 Suppl 1:140-142.

9. Emamaullee JA, Shapiro AM. Interventional strategies to prevent beta-cell apoptosis in islet transplantation. Diabetes. 2006;55(7):1907-1914.

10. Shapiro AM, Lakey JR, Ryan EA, et al. Islet transplantation in seven patients with type 1 diabetes mellitus using a glucocorticoid-free immunosuppressive regimen. N Engl J Med. 2000;343(4):230-238.

11. Ryan EA, Bigam D, Shapiro AM. Current indications for pancreas or islet transplant. Diabetes Obes Metab. 2006;8(1):1-7.

12. Scharp DW, Kemp CB, Knight MJ, Ballinger WF, Lacy PE. The use of ficoll in the preparation of viable islets of langerhans from the rat pancreas. Transplantation. 1973;16(6):686-689.

13. Najarian JS, Sutherland DE, Matas AJ, Steffes MW, Simmons RL, Goetz FC. Human islet transplantation: a preliminary report. Transplant Proc. 1977;9(1):233-236.

14. Brendel M, Hering B, Shulz A, Bretzel R. International Islet Transplant Registry Report. Giessen, Germany: University of Giessen; 1999:1-20.

15. The CITR Coordinating Center and Investigators. The Collaborative Islet Transplant Registry (CITR) 2011 Seventh Annual Report. US Department of Health and Human Services, Bethesda, MA, USA; 2011. Available from https://web.emmes.com/study/isl/reports/01062012_7thAnnual Report.pdf. Accessed April 9, 2014.

16. Ly TT, Nicholas JA, Retterath A, Lim EM, Davis EA, Jones TW. Effect of sensor-augmented insulin pump therapy and automated insulin suspension vs standard insulin pump therapy on hypoglycemia in patients with type 1 diabetes: a randomized clinical trial. JAMA. 2013;310(12):1240-1247.

17. Shapiro AM. Strategies toward single-donor islets of Langerhans transplantation. Curr Opin Organ Transplant. 2011;16(6):627-631.

18. Thompson DM, Meloche M, Ao Z, et al. Reduced progression of diabetic microvascular complications with islet cell transplantation compared with intensive medical therapy. Transplantation. 2011;91(3): 373-378.

19. Barton FB, Rickels MR, Alejandro R, et al. Improvement in outcomes of clinical islet transplantation: 1999-2010. Diabetes Care. 2012;35(7): 1436-1445.

20. Senior PA, Kin T, Shapiro AMJ, Koh A. Islet transplantation at the University of Alberta: status update and review of progress over the last decade. Can J Diabetes. 2012;36:32-37.

21. Merani S, Shapiro AM. Current status of pancreatic islet transplantation. Clin Sci (Lond). 2006;110(6):611-625.

22. Pepper AR, Gala-Lopez B, Ziff O, Shapiro AJ. Current status of clinical islet transplantation. World J Transplant. 2013;3(4):48-53.

23. Benhamou PY, Watt PC, Mullen Y, et al. Human islet isolation in 104 consecutive cases. Factors affecting isolation success. Transplantation. 1994;57(12):1804-1810.

24. Goto M, Eich TM, Felldin M, et al. Refinement of the automated method for human islet isolation and presentation of a closed system for in vitro islet culture. Transplantation. 2004;78(9):1367-1375.

25. Ihm SH, Matsumoto I, Sawada T, et al. Effect of donor age on function of isolated human islets. Diabetes. 2006;55(5):1361-1368.

26. Lakey JR, Rajotte RV, Warnock GL, Kneteman NM. Human pancreas preservation prior to islet isolation. Cold ischemic tolerance. Transplantation. 1995;59(5):689-694.

27. Lakey JR, Warnock GL, Rajotte RV, et al. Variables in organ donors that affect the recovery of human islets of Langerhans. Transplantation. 1996;61(7):1047-1053.

28. Matsumoto I, Sawada T, Nakano M, et al. Improvement in islet yield from obese donors for human islet transplants. Transplantation. 2004;78(6):880-885. 
29. Nano R, Clissi B, Melzi R, et al. Islet isolation for allotransplantation: variables associated with successful islet yield and graft function. Diabetologia. 2005;48(5):906-912.

30. Zeng Y, Torre MA, Karrison T, Thistlethwaite JR. The correlation between donor characteristics and the success of human islet isolation. Transplantation. 1994;57(6):954-958.

31. Kin T, Murdoch TB, Shapiro AM, Lakey JR. Estimation of pancreas weight from donor variables. Cell Transplant. 2006;15(2):181-185.

32. Brandhorst H, Brandhorst D, Hering BJ, Federlin K, Bretzel RG. Body mass index of pancreatic donors: a decisive factor for human islet isolation. Exp Clin Endocrinol Diabetes. 1995;103 Suppl 2:23-26.

33. Berney T, Johnson PR. Donor pancreata: evolving approaches to organ allocation for whole pancreas versus islet transplantation. Transplantation. 2010;90(3):238-243

34. O'Gorman D, Kin T, Murdoch T, et al. The standardization of pancreatic donors for islet isolation. Transplant Proc. 2005;37(2):1309-1310.

35. Witkowski P, Liu Z, Cernea S, et al. Validation of the scoring system for standardization of the pancreatic donor for islet isolation as used in a new islet isolation center. Transplant Proc. 2006;38(9):3039-3040.

36. Noguchi H. Pancreas procurement and preservation for islet transplantation: personal considerations. J Transplant. 2011;2011:783168.

37. Saito T, Gotoh M, Satomi S, et al; Working Members of The Japanese Pancreas and Islet Transplantation Association. Islet transplantation using donors after cardiac death: report of the Japan Islet Transplantation Registry. Transplantation. 2010;90(7):740-747.

38. Wolters GH, Vos-Scheperkeuter GH, van Deijnen JH, van Schilfgaarde R. An analysis of the role of collagenase and protease in the enzymatic dissociation of the rat pancreas for islet isolation. Diabetologia. 1992;35(8):735-742.

39. Wang X, Meloche M, Verchere CB, Ou D, Mui A, Warnock GL. Improving islet engraftment by gene therapy. J Transplant. 2011;2011:594851.

40. Ichii H, Pileggi A, Khan A, Fraker C, Ricordi C. Culture and transportation of human islets between centers. In: Shapiro AMJ, Shaw JAM, editors. Islet Transplantation and Beta Cell Replacement Therapy. New York: Informa Healthcare; 2007:251-268.

41. Nagata NA, Inoue K, Tabata Y. Co-culture of extracellular matrix suppresses the cell death of rat pancreatic islets. J Biomater Sci Polym Ed. 2002;13(5):579-590.

42. Lakey JR, Woods EJ, Zieger MA, et al. Improved islet survival and in vitro function using solubilized small intestinal submucosa. Cell Tissue Bank. 2001;2(4):217-224.

43. Gatto C, Callegari M, Folin M, et al. Effects of cryopreservation and coculture with pancreatic ductal epithelial cells on insulin secretion from human pancreatic islets. Int J Mol Med. 2003;12(6):851-854.

44. Velmurugan K, Balamurugan AN, Loganathan G, Ahmad A, Hering BJ, Pugazhenthi S. Antiapoptotic actions of exendin-4 against hypoxia and cytokines are augmented by CREB. Endocrinology. 2012;153(3):1116-1128.

45. Bloch K, Vennang J, Lazard D, Vardi P. Different susceptibility of rat pancreatic alpha and beta cells to hypoxia. Histochem Cell Biol. 2012;137(6):801-810.

46. Narang AS, Cheng K, Henry J, et al. Vascular endothelial growth factor gene delivery for revascularization in transplanted human islets. Pharm Res. 2004;21(1):15-25.

47. Emamaullee JA, Shapiro AM. Factors influencing the loss of beta-cell mass in islet transplantation. Cell Transplant. 2007;16(1):1-8.

48. Merani S, Toso C, Emamaullee J, Shapiro AM. Optimal implantation site for pancreatic islet transplantation. Br J Surg. 2008;95(12):1449-1461.

49. Gibly RF, Graham JG, Luo X, Lowe WL Jr, Hering BJ, Shea LD. Advancing islet transplantation: from engraftment to the immune response. Diabetologia. 2011;54(10):2494-2505.

50. Wang RN, Rosenberg L. Maintenance of beta-cell function and survival following islet isolation requires re-establishment of the islet-matrix relationship. J Endocrinol. 1999;163(2):181-190.

51. Barshes NR, Wyllie S, Goss JA. Inflammation-mediated dysfunction and apoptosis in pancreatic islet transplantation: implications for intrahepatic grafts. J Leukoc Biol. 2005;77(5):587-597.
52. Carlsson PO, Palm F, Andersson A, Liss P. Chronically decreased oxygen tension in rat pancreatic islets transplanted under the kidney capsule. Transplantation. 2000;69(5):761-766.

53. Carlsson PO, Palm F, Andersson A, Liss P. Markedly decreased oxygen tension in transplanted rat pancreatic islets irrespective of the implantation site. Diabetes. 2001;50(3):489-495.

54. Plesner A, Verchere CB. Advances and challenges in islet transplantation: islet procurement rates and lessons learned from suboptimal islet transplantation. J Transplant. 2011;2011:979527.

55. Goto M, Tjernberg J, Dufrane D, et al. Dissecting the instant blood-mediated inflammatory reaction in islet xenotransplantation. Xenotransplantation. 2008;15(4):225-234.

56. Vivot K, Jeandidier N, Dollinger C, et al. Role of islet culture on angiogenic and inflammatory mechanisms. Transplant Proc. 2011;43(9): 3201-3204.

57. Nilsson B, Ekdahl KN, Korsgren O. Control of instant blood-mediated inflammatory reaction to improve islets of Langerhans engraftment. Curr Opin Organ Transplant. 2011;16(6):620-626.

58. Ji M, Yi S, Smith-Hurst H, et al. The importance of tissue factor expression by porcine NICC in triggering IBMIR in the xenograft setting. Transplantation. 2011;91(8):841-846.

59. Ma X, Ye B, Gao F, et al. Tissue factor knockdown in porcine islets: an effective approach to suppressing the instant blood-mediated inflammatory reaction. Cell Transplant. 2012;21(1):61-71.

60. Ozmen L, Ekdahl KN, Elgue G, Larsson R, Korsgren O, Nilsson B. Inhibition of thrombin abrogates the instant blood-mediated inflammatory reaction triggered by isolated human islets: possible application of the thrombin inhibitor melagatran in clinical islet transplantation. Diabetes. 2002;51(6):1779-1784.

61. Yasunami Y, Kojo S, Kitamura H, et al. Valpha14 NK T cell-triggered IFN-gamma production by Gr-1+CD11b+cells mediates early graft loss of syngeneic transplanted islets. J Exp Med. 2005;202(7):913-918.

62. Bloom SR, Polak JM. Somatostatin. Br Med J (Clin Res Ed). 1987;295(6593):288-290.

63. Korsgren O, Lundgren T, Felldin M, et al. Optimising islet engraftment is critical for successful clinical islet transplantation. Diabetologia. 2008;51(2):227-232.

64. Wu Z, Liu S, Hassink M, et al. Development and evaluation of 18F-TTCO-Cys40-Exendin-4: a PET probe for imaging transplanted islets. J Nucl Med. 2013;54(2):244-251.

65. Toso C, Vallee JP, Morel P, et al. Clinical magnetic resonance imaging of pancreatic islet grafts after iron nanoparticle labeling. Am J Transplant. 2008;8(3):701-706.

66. Medarova Z, Moore A. MRI as a tool to monitor islet transplantation. Nat Rev Endocrinol. 2009;5(8):444-452.

67. Oishi K, Miyamoto Y, Saito H, et al. In vivo imaging of transplanted islets labeled with a novel cationic nanoparticle. PloS One. 2013;8(2):e57046.

68. Eich T, Eriksson O, Lundgren T; Nordic Network for Clinical Islet Transplantation. Visualization of early engraftment in clinical islet transplantation by positron-emission tomography. New Engl J Med. 2007;356(26):2754-2755.

69. Eriksson O, Alavi A. Imaging the islet graft by positron emission tomography. Eur J Nucl Med Mol Imaging. 2012;39(3):533-542.

70. Rajab A. Islet transplantation: alternative sites. Curr Diab Rep. 2010;10(5):332-337.

71. Barshes NR, Lee TC, Goodpastor SE, et al. Transaminitis after pancreatic islet transplantation. J Am Coll Surg. 2005;200(3):353-361.

72. Veriter S, Gianello P, Dufrane D. Bioengineered sites for islet cell transplantation. Curr Diab Rep. 2013;13(5):745-755.

73. Lacy PE, Ricordi C, Finke EH. Effect of transplantation site and alpha L3T4 treatment on survival of rat, hamster, and rabbit islet xenografts in mice. Transplantation. 1989;47(5):761-766.

74. Mellgren A, Schnell Landstrom AH, Petersson B, Andersson A. The renal subcapsular site offers better growth conditions for transplanted mouse pancreatic islet cells than the liver or spleen. Diabetologia. 1986;29(9):670-672. 
75. Jindal RM, Sidner RA, McDaniel HB, Johnson MS, Fineberg SE. Intraportal vs kidney subcapsular site for human pancreatic islet transplantation. Transplant Proc. 1998;30(2):398-399.

76. Pepper AR, Gala-Lopez B, Ziff O, Shapiro AM. Revascularization of transplanted pancreatic islets and role of the transplantation site. Clin Dev Immunol. 2013;2013:352315.

77. Dufrane D, Goebbels RM, Gianello P. Alginate macroencapsulation of pig islets allows correction of streptozotocin-induced diabetes in primates up to 6 months without immunosuppression. Transplantation. 2010;90(10):1054-1062.

78. Rafael E, Wu GS, Hultenby K, Tibell A, Wernerson A. Improved survival of macroencapsulated islets of Langerhans by preimplantation of the immunoisolating device: a morphometric study. Cell Transplant. 2003;12(4):407-412.

79. Sorenby AK, Kumagai-Braesch M, Sharma A, Hultenby KR, Wernerson AM, Tibell AB. Preimplantation of an immunoprotective device can lower the curative dose of islets to that of free islet transplantation: studies in a rodent model. Transplantation. 2008;86(2): 364-366.

80. Barkai U, Weir GC, Colton CK, et al. Enhanced oxygen supply improves islet viability in a new bioartificial pancreas. Cell Transplant. 2013;22(8):1463-1476.

81. Ludwig B, Reichel A, Steffen A, et al. Transplantation of human islets without immunosuppression. Proc Natl Acad Sci U SA. 2013;110(47): 19054-19058.

82. D'Amour KA, Bang AG, Eliazer S, et al. Production of pancreatic hormone-expressing endocrine cells from human embryonic stem cells. Nat Biotechnol. 2006;24(11):1392-1401.

83. Kroon E, Martinson LA, Kadoya K, et al. Pancreatic endoderm derived from human embryonic stem cells generates glucose-responsive insulinsecreting cells in vivo. Nat Biotechnol. 2008;26(4):443-452.

84. Schulz TC, Young HY, Agulnick AD, et al. A scalable system for production of functional pancreatic progenitors from human embryonic stem cells. PloS One. 2012;7(5):e37004.

85. Ryan EA, Paty BW, Senior PA, et al. Five-year follow-up after clinical islet transplantation. Diabetes. 2005;54(7):2060-2069.

86. Gala-Lopez B, Pepper AR, Shapiro AM. Biologic agents in islet transplantation. Curr Diab Rep. 2013;13(5):713-722.

87. Gabardi S, Martin ST, Roberts KL, Grafals M. Induction immunosuppressive therapies in renal transplantation. Am J Health Syst Pharm. 2011;68(3):211-218.

88. Hering BJ. Repurification: rescue rather than routine remedy. Am J Transplant. 2005;5(1):1-2.

89. Hering BJ, Kandaswamy R, Ansite JD, et al. Single-donor, marginaldose islet transplantation in patients with type 1 diabetes. JAMA. 2005;293(7):830-835.

90. Koh A, Senior P, Salam A, et al. Insulin-heparin infusions peritransplant substantially improve single-donor clinical islet transplant success. Transplantation. 2010;89(4):465-471.

91. Matsumoto S, Takita M, Chaussabel D, et al. Improving efficacy of clinical islet transplantation with iodixanol based islet purification, thymoglobulin induction and blockage of IL-1-beta and TNF-alpha. Cell Transplant. 2011;20(10):1641-1647.

92. Shapiro AM, Ricordi C. Unraveling the secrets of single donor success in islet transplantation. Am J Transplant. 2004;4(3):295-298.

93. Xenos ES, Farney AC, Widmer MB, et al. Effect of tumor necrosis factor alpha and of the soluble tumor necrosis factor receptor on insulin secretion of isolated islets of Langerhans. Transplant Proc. 1992;24(6): 2863-2864.

94. Bhatt S, Fung JJ, Lu L, Qian S. Tolerance-inducing strategies in islet transplantation. Int J Endocrinol. 2012;2012:396524.

95. Shapiro AM, Nanji SA, Lakey JR. Clinical islet transplant: current and future directions towards tolerance. Immunol Rev. 2003;196: 219-236.
96. Posselt AM, Szot GL, Frassetto LA, et al. Islet transplantation in type 1 diabetic patients using calcineurin inhibitor-free immunosuppressive protocols based on T-cell adhesion or costimulation blockade. Transplantation. 2010;90(12):1595-1601.

97. Skyler JS, Ricordi C. Stopping type 1 diabetes: attempts to prevent or cure type 1 diabetes in man. Diabetes. 2011;60(1):1-8.

98. Skyler JS; Type 1 Diabetes TrialNet Study Group. Update on worldwide efforts to prevent type 1 diabetes. Ann NY Acad Sci. 2008;1150: 190-196.

99. Baekkeskov S, Aanstoot HJ, Christgau S, et al. Identification of the $64 \mathrm{~K}$ autoantigen in insulin-dependent diabetes as the GABA-synthesizing enzyme glutamic acid decarboxylase. Nature. 1990;347(6289): $151-156$.

100. Tian J, Clare-Salzler M, Herschenfeld A, et al. Modulating autoimmune responses to GAD inhibits disease progression and prolongs islet graft survival in diabetes-prone mice. Nat Med. 1996;2(12): 1348-1353.

101. Pleau JM, Fernandez-Saravia F, Esling A, Homo-Delarche F, Dardenne M. Prevention of autoimmune diabetes in nonobese diabetic female mice by treatment with recombinant glutamic acid decarboxylase (GAD 65). Clin Immunol Immunopathol. 1995;76(1 Pt 1): 90-95.

102. Wherrett DK, Bundy B, Becker DJ, et al; Type 1 Diabetes TrialNet GAD Study Group. Antigen-based therapy with glutamic acid decarboxylase (GAD) vaccine in patients with recent-onset type 1 diabetes: a randomised double-blind trial. Lancet. 2011;378(9788):319-327.

103. Tisch R, Yang XD, Liblau RS, McDevitt HO. Administering glutamic acid decarboxylase to NOD mice prevents diabetes. J Autoimmun. 1994;7(6):845-850.

104. Belghith M, Bluestone JA, Barriot S, Megret J, Bach JF, Chatenoud L. TGF-beta-dependent mechanisms mediate restoration of self-tolerance induced by antibodies to CD3 in overt autoimmune diabetes. Nat Med. 2003;9(9):1202-1208.

105. Chatenoud L, Primo J, Bach JF. CD3 antibody-induced dominant self tolerance in overtly diabetic NOD mice. J Immunol. 1997;158(6): 2947-2954.

106. Skyler JS. The compelling case for anti-CD3 in type 1 diabetes. Diabetes. 2013;62(11):3656-3657.

107. Chatenoud L, Thervet E, Primo J, Bach JF. Anti-CD3 antibody induces long-term remission of overt autoimmunity in nonobese diabetic mice. Proc Natl Acad Sci U SA. 1994;91(1):123-127.

108. Keymeulen B, Walter M, Mathieu C, et al. Four-year metabolic outcome of a randomised controlled $\mathrm{CD} 3$-antibody trial in recent-onset type 1 diabetic patients depends on their age and baseline residual beta cell mass. Diabetologia. 2010;53(4):614-623.

109. Cook JJ, Hudson I, Harrison LC, et al. Double-blind controlled trial of azathioprine in children with newly diagnosed type I diabetes. Diabetes. 1989;38(6):779-783.

110. Elliott RB, Crossley JR, Berryman CC, James AG. Partial preservation of pancreatic beta-cell function in children with diabetes. Lancet. 1981;2(8247):631-632.

111. Harrison LC, Colman PG, Dean B, Baxter R, Martin FI. Increase in remission rate in newly diagnosed type I diabetic subjects treated with azathioprine. Diabetes. 1985;34(12):1306-1308.

112. Silverstein J, Maclaren N, Riley W, Spillar R, Radjenovic D, Johnson S. Immunosuppression with azathioprine and prednisone in recent-onset insulin-dependent diabetes mellitus. New Engl J Med. 1988;319(10):599-604.

113. Voltarelli JC, Couri CE, Stracieri AB, et al. Autologous nonmyeloablative hematopoietic stem cell transplantation in newly diagnosed type 1 diabetes mellitus. JAMA. 2007;297(14):1568-1576. 
Diabetes, Metabolic Syndrome and Obesity: Targets and Therapy

Dovepress

\section{Publish your work in this journal}

Diabetes, Metabolic Syndrome and Obesity: Targets and Therapy is opinion and commentaries are all considered for publication. The an international, peer-reviewed open-access journal committed to the rapid publication of the latest laboratory and clinical findings in the fields of diabetes, metabolic syndrome and obesity research. Original research, review, case reports, hypothesis formation, expert manuscript management system is completely online and includes a very quick and fair peer-review system, which is all easy to use. Visit $\mathrm{http}: / / \mathrm{www}$.dovepress.com/testimonials.php to read real quotes from published authors.

Submit your manuscript here: http://www.dovepress.com/diabetes-metabolic-syndrome-and-obesity-targets-and-therapy-journal 